\title{
Profiling of 54 plasma glycoproteins by label-free targeted LC-MS/MS
}

Lina A. Dahabiyeh ${ }^{1,3}$, David Tooth ${ }^{2}$, and David A. Barrett ${ }^{3 *}$

1 Department of Pharmaceutical Sciences, School of Pharmacy, The University of Jordan, Amman, Jordan.

${ }^{2}$ School of Life Sciences, Centre for Biomolecular Sciences, University of Nottingham, Nottingham NG7 2RD, UK

${ }^{3}$ Centre for Analytical Bioscience, Advanced Materials and Healthcare Technologies Division, School of Pharmacy, University of Nottingham, University Park, Nottingham NG7 2RD, UK

\section{*Correspondence}

David A. Barrett

Centre for Analytical Bioscience, Advanced Materials and Healthcare Technologies Division, School of Pharmacy, University of Nottingham, University Park, Nottingham NG7 2RD, UK

Telephone: 01159515062 Fax: 01159515102

Email: David.Barrett@nottingham.ac.uk 


\section{Abstract}

Glycoproteins play a central role in diverse biological processes and are linked with many serious human diseases. In this paper we present a simple, reproducible and cost-effective analytical workflow that enables the reliable quantification of clinically relevant human plasma glycoproteins using label free microflow LC-MS/MS analysis.

Plasma $N$-glycoproteins were selectively extracted via ConA Sepharose lectin affinity chromatography then separated into two fractions using reversed-phase solid phase extraction. LC-MS/MS analysis of the tryptic digest of both fractions identified 90 proteins from which 54 clinically relevant glycoproteins were selected for protein profiling. Careful assessment of the chosen peptides and transitions in terms of reproducibility, selectivity, signal intensity and peak shape was carried out. Measurement of the analytical precision of the method revealed the majority of glycoproteins showed a coefficient of variation (CV) $\leq 15 \%$ (median CV $11.8 \%$, range 3.6-33\%). The method was successfully applied to compare glycoproteins in plasma and serum and to detect changes in glycoprotein profile in perturbed plasma pre-treated with ammonium sulphate. Our results show that label-free methodology can be a cost-effective affordable alternative to stable isotope standard workflow when applied for relative protein quantification, especially when targeting a large number of proteins in bioanalytical measurements.

Keywords: Glycoprotein, Label-free, Targeted LC-MS/MS, ConA, RP-SPE, Stable isotope standard 


\section{Introduction}

Glycoproteins represent a major class of the human plasma proteome with more than $50 \%$ of proteins being glycosylated [1] and are involved in many important biological processes such as cell signalling pathways, cell division and immunological reactions [2]. Specific glycoproteins have been identified as potential disease biomarkers and therapeutic targets in a range of human diseases (e.g Her2/neu in breast cancer [3], prostate-specific antigen in prostate cancer [4], and vascular cell adhesion molecule 1 in rheumatoid arthritis [5]). These glycoproteins have the potential to provide a better understanding of the biochemical mechanisms underlying pathologies [5-8]. Therefore, measuring the changes in glycoprotein profiles between diseased and non-diseased states can make a fundamental contribution to diagnostic and prognostic clinical science.

Most glycoprotein analysis has focused on $N$-glycoproteins which are predominant in the extracellular matrix (e.g. secreted forms) and in biofluids such as blood plasma, cerebrospinal fluid, urine and saliva [9]. Two strategies namely, lectin affinity chromatography and hydrazide chemistry, have demonstrated effective extraction of $\mathrm{N}$-glycoproteins and $\mathrm{N}$ glycopeptides from complex biological samples [10, 11]. In hydrazide chemistry, $N$ glycoproteins are extracted by a chemical reaction between the hydrazide group of the immobilised bead and the dialdehyde group derived from the glycan moiety of the glycoprotein [9]. The second strategy, lectin affinity, has become a common and powerful tool for the selective capture of a wide range of glycoproteins [6]. Different lectins with variable, but partially overlapping, binding profiles can recognise and bind to specific carbohydrate residues on glycoproteins [12]. Commonly, two or more lectins with complementary specificities for different glycosylation structures are used in multi-lectin affinity enrichment to provide a more comprehensive coverage for the glycoproteome of interest [13]. 
Concanavalin A (ConA) is a lectin which preferentially recognises mannosyl oligosaccharides, and to lesser extent glucosyl oligosaccharides, attached to proteins through asparagine residues. This type of carbohydrate is commonly present in a wide variety of serum glycoproteins and, therefore, ConA is the most commonly used lectin for $\mathrm{N}$ glycoprotein isolation [14]. ConA is a readily available, low cost, high affinity ligand with a relatively broad specificity which allows for the selective isolation of the majority of glycoproteins in a plasma sample [15] .

Given their high sensitivity and selectivity, mass spectrometry-based methods are widely used to identify and quantify glycoproteins, recognise glycosylation sites, and characterise the attached oligosaccharides [16]. Targeted glycoprotein quantification by LC-MS/MS provides an improved sensitivity and specificity when compared to shotgun glycoproteomics workflows [7, 17]. A targeted approach can be used for relative or absolute protein quantification applying either stable isotope standards (SIS), reference-labelled peptides or label-free workflows [18]. SIS is considered the gold standard method for absolute quantification and, therefore, most of the reported targeted glycoprotein profiling studies used this workflow for plasma glycoprotein measurements. However, SIS method is limited by the high cost of the labelled peptide standards which creates an obstacle for the routine use of this methodology, especially for large numbers of clinical samples and/or when a large number of glycoproteins require simultaneous monitoring [19]. As a result, a relatively small numbers of plasma glycoproteins (less than 15 glycoproteins) have been profiled simultaneously by previous glycoprotein methods $[20,21]$. The reference-labelled peptide strategy involves a single isotopically labelled peptide used as a reference for the normalisation of all peptides monitored whilst in the label-free strategy, the raw peak areas of the monitored peptides are compared between different conditions [18]. Although label-free methodology is generally associated with higher variability than SIS [18], careful method development and validation 
can provide acceptable analytical precision. Additionally, a label free approach has the advantage of not being limited to a specific set of glycoproteins. This prompted us to develop a simple and more cost-effective targeted LC-MS/MS methodology using a label-free workflow to provide a cost- and time-effective solution to the measurement of a large number of glycoproteins simultaneously. Here we present a reproducible label-free targeted LCMS/MS method adapted to a standard microflow LC-MS/MS system with the ability to achieve high throughput profiling of more than fifty plasma glycoproteins most of which are biomarkers of disease and very few of them have been jointly investigated in the same sample set previously. We also show the application of the developed method to modified blood plasma and serum intended to represent perturbed change.

\section{Materials and Methods}

\subsection{Plasma and serum samples}

Human blood plasma and serum were obtained from a healthy volunteer with informed consent following approval from the School of Pharmacy Research Ethics Committee, University of Nottingham, UK. For control plasma; blood was collected into EDTA tube, and immediately after collection and mixing, the blood sample was centrifuged at 1000x $g$ for 15 min. For serum; blood was collected into serum separation tubes (BD Vacutainer ${ }^{\circledR} \mathrm{SST}^{\mathrm{TM}}$ ), inverted several times, allowed 30 minutes clotting time, and centrifuged for 15 minutes at $1000 \mathrm{x}$. The separated plasma and serum were stored in $0.5 \mathrm{~mL}$ aliquots at $-80^{\circ} \mathrm{C}$ for subsequent analysis.

\subsection{Extraction of glycoprotein by 2-dimensional chromatography using ConA lectin affinity} and reversed-phase modes

Concanavalin A-Sepharose 4B (ConA, Sigma-Aldrich, UK) resin slurry (100 $\mu$ L) was placed into micro-tube filter devices (Spin- $\mathrm{X}^{\circledR}$, Corning Inc.) to provide a 1:1 ratio of resin bed to 
sample volume, and conditioned with 3 x $0.3 \mathrm{~mL}$ washing buffer (50 mM TRIS pH 7.4, 0.15 $\left.\mathrm{M} \mathrm{NaCl}, 1 \mathrm{mM} \mathrm{CaCl} 2, \mathrm{MgCl}_{2}, \mathrm{MnCl}_{2}\right)$. Plasma samples $(50 \mu \mathrm{L})$, were diluted in $250 \mu \mathrm{L}$ washing buffer, loaded onto the conditioned resin and incubated at room temperature for 20 min with agitation. The resin was washed three times, as before, with the washing buffer and retained glycoproteins were recovered with four step-wise additions of $300 \mu \mathrm{L}$ elution buffer (0.40 M methyl $\alpha$-D-mannopyranoside (Sigma-Aldrich, UK) in washing buffer), which were pooled $(1.2 \mathrm{~mL})$ for subsequent reversed phase solid-phase extraction (RP-SPE) fractionation. Polymeric large-pore RP-SPE cartridges (Biotage UK, IST ISOLUTE, PDVB, $1000 \AA$, 25 mg) were wetted with $1 \mathrm{~mL}$ of $0.1 \%(v / v)$ TFA in $90 \%$ acetonitrile prior to conditioning with $1 \mathrm{~mL}$ of $0.1 \%$ TFA in water. The enriched glycoprotein samples were loaded onto the preconditioned SPE cartridge and washed with $1 \mathrm{~mL} 0.1 \%$ TFA. The retained proteins were sequentially eluted with $1 \mathrm{~mL}$ of $30,35,40,43,45,48,50$, and $90 \%(v / v)$ acetonitrile in $0.1 \%$ TFA in water and the collected fractions $(n=8)$ were dried using vacuum centrifugation [22].

\subsection{Digestion of RP-SPE glycoprotein fractions}

To increase the throughput of the method, ConA captured proteins were collected by RP-SPE into two fractions; A and B representing glycoproteins eluted at $40 \%$ and $50 \% 0.1 \%$ TFA acetonitrile in $0.1 \%$ TFA water $(v / v)$. Proteins in each fraction were denatured with $6 \mathrm{M}$ urea and reduced with $50 \mathrm{mM}$ DTT followed by alkylation with $200 \mathrm{mM}$ iodoacetamide. All reactions were carried out at $37^{\circ} \mathrm{C}$ for $30 \mathrm{~min}$ in the dark using filter assisted preparation (FASP) (10 kDa Amicon ultra 0.5 Sigma-Aldrich, UK). After each reaction, the sample was washed twice with $400 \mu \mathrm{L}$ of $50 \mathrm{mM}$ ammonium hydrogen carbonate at $14000 \mathrm{x} g$ for $7 \mathrm{~min}$. Protein digestion was carried out using MS grade trypsin gold (Promega, UK) at $37^{\circ} \mathrm{C}$ using an enzyme:protein ratio of 1:50 (w/w). To ensure more complete digestion, a second aliquot of trypsin $(1: 100$ enzyme: protein $w / w)$ was added after $4 \mathrm{~h}$ and digestion proceeded at $37^{\circ} \mathrm{C}$ 
overnight. The reaction was quenched with $1 \%$ formic acid, centrifuged for 5 min at 11000x $g$ and (90\% of) the upper layer was transferred for LC-MS/MS analysis.

\subsection{LC-MS/MS analysis of plasma glycoprotein in RP-SPE fractions}

An ion trap mass spectrometer coupled to UPLC (Thermo Fisher LTQ Velos, Thermo Fisher Scientific, CA, USA) operating in positive-ion ESI mode was used to analyse the tryptic peptide digests of the two RP-SPE fractions and two separate LC-MS/MS runs were made for each sample representing proteins in fractions A and B. Peptides were separated on a C18, 3 $\mu \mathrm{m} 300 \AA, 100 \times 2.1 \mathrm{~mm}$ column (ACE, Reading, UK), using a mobile phase gradient of 10 to $45 \%$ acetonitrile in water both with $0.1 \%$ formic acid over $15 \mathrm{~min}$ at $300 \mu \mathrm{L} / \mathrm{min}$ flow rate. ESI source parameters were: ion spray voltage $3 \mathrm{kV}$, capillary and source heater temperatures $275^{\circ} \mathrm{C}$ and $300^{\circ} \mathrm{C}$ respectively and the flow rate for the sheath, auxiliary and sweep gases were 30, 20 and 10 arbitrary units respectively. MS/MS spectra were acquired by data dependant acquisition (DDA) in full scan mode $(\mathrm{m} / \mathrm{z}, 350-1650)$ with the precursor ions dynamically selected and subjected to collision induced dissociation (CID) performed at a normalised value of $35 \%$.

\subsection{Identification of plasma glycoprotein in RP-SPE fractions}

The MS/MS ion search option in Mascot search engine (version 2.3.01; Matrix Science Inc., London, UK) was selected to search against all Homo sapiens entries in the Swiss-Prot database for protein identification applying the following search parameters: trypsin enzyme, one missed cleavage, peptide mass tolerance of 1.2 Da, MS/MS tolerance of 0.6 Da, fixed modification carbamidomethylation of cysteines, variable oxidation of methionines and peptide charge of $1+, 2+$, and $3+$. Decoy tool was selected for all searches to adjust the 
significance threshold for a global false discovery rate (FDR) at $1 \%$. Proteins not reliably identified between replicates were not included in the final list of the identified glycoproteins.

\subsection{Plasma glycoprotein profiling by targeted LC-MS/MS}

Fifty-four glycoproteins with a high confidence of identity were selected for protein profiling by targeted LC-MS/MS. One signature peptide per protein was used in the assay with 1,2 or 3 SRM transition(s) per peptide being monitored.

Two separate LC-MS/MS runs of trypsin digested peptides were made for each sample representing proteins monitored in fractions A and B., using a 4000 QTRAP hybrid triple quadrupole/linear ion trap mass spectrometer (Applied Biosystems, CA, USA) operating in positive ion mode. Peptides were first separated by a Shimadzu series 10AD VP LC system (Shimadzu, Columbia, MD) using C18 $3 \mu \mathrm{m} 300 \AA$ Å, 100x1mm column (ACE, Reading, UK) and a mobile phase gradient of 10 to $45 \%$ acetonitrile in water both with $0.1 \%$ formic acid over $15 \mathrm{~min}$ at $100 \mu \mathrm{L} / \mathrm{min}$ flow rate. Multiple reaction monitoring (MRM) transitions were monitored and acquired at unit resolution in both Q1 and Q3 and were used to trigger enhanced product ion (EPI) scan in the linear ion trap of the QTRAP in the mass range $m / z$ 100-1500 to confirm the surrogate peptide sequence. The optimised values for curtain gas, collision gas, GS1 and GS2 were 10, 9, 30 and 45 arbitrary units respectively. The heated capillary temperature was maintained at $450^{\circ} \mathrm{C}$ and the ESI voltage was kept at $4200 \mathrm{~V}$.

All MRM and EPI data were processed with Analyst software 1.4.2.

\subsection{Method performance}

Most of the selected signature peptides together with their MRM transitions were from available relevant scientific literature [23-26]. Where such data was not available, the MS/MS data obtained from Mascot were used to choose signature peptides for the remaining proteins 
and careful assessment of the chosen peptides and transitions based upon highest signal intensities and chromatographic peak shapes were used. All monitored signature peptides had already been identified in Mascot searches during glycoprotein identification.

Although one signature peptide per protein was used in the final assay, for many proteins two or three signature peptides were evaluated initially (e.g. fibronectin, pigment epithelium derived factor), and the best one in terms of sensitivity, selectivity and peak shape was chosen. Additionally, more than one product ion per peptide was monitored and the resulting MS/MS spectra were manually inspected. Transitions that yielded the best signal intensity, specificity (no interferences from background matrix), and peak shape for integration were selected for subsequent validation. For most peptides one transition was used in the final assay, however monitoring two or three fragments was necessary for the remainders (Table 2). Where possible, the highest intensity fragment ion $(+1)$ with $\mathrm{m} / z$ greater than the precursor ion (+2) was selected to increase the sensitivity and selectivity of the assay.

MRM results from the above assessment were pooled, and a set of optimised 56 MRM channels that covered 39 and 33 proteins in fractions A and B respectively was obtained, with glycoproteins monitored in both fractions also indicated (Table 2).

Quantitative assessment of the analytical precision was evaluated by measuring the coefficient of variation (CV\%) for the selected glycoproteins between six replicate human plasma controls and CV values of $\leq 15 \%$ were considered acceptable, in accordance with the US-FDA bioanalytical method validation, guidance for industry, May 2018 [27].

\subsection{Application of the developed method to ammonium sulphate treated plasma}

To confirm the ability of the profiling method to reproducibly detect differences in glycoprotein abundance, modified human plasma samples were created by pre-treatment with ammonium sulphate; a common approach in protein sample preparation for the selective 
precipitation of proteins. Solid ammonium sulphate $(80 \mathrm{mg})$ was added slowly, in four additions, to $1 \mathrm{~mL}$ chilled plasma with stirring to achieve a final $15 \%(w / w)$ saturated level. This low concentration of ammonium sulphate, $15 \%(w / w)$, was used to induce minor changes in the level of some of the targeted plasma glycoproteins. Following complete dissolution, the plasma was centrifuged at $12000 \mathrm{x} g$ for $15 \mathrm{~min}$, and $50 \mu \mathrm{L}$ of the supernatant was taken for subsequent glycoprotein extraction and MS profiling as described in the above sections. Relative fold changes in the level of the 54 profiled glycoproteins were measured by comparing the average of the peak areas of each signature peptide between plasma controls $(n=6)$ and ammonium sulphate treated plasma samples $(n=6)$. For glycoproteins monitored in both fractions, $\mathrm{A}$ and $\mathrm{B}$, (Table 2) relative fold changes were measured by combining the peak areas of the MRM assay in both fractions then comparing the average of the combined peak areas of each signature peptide between the two test conditions.

\section{Results and Discussion}

\subsection{Extraction of glycoproteins by ConA resin and RP-SPE}

Following ConA enrichment, approximately $70 \%$ of the total plasma proteins were depleted and $22 \%$ were captured by the ConA resin (Table 1). Recoveries of the depleted proteins and the ConA bound fractions across the replicates were reproducible with standard deviation (SD) between $1-3 \%$ (Table 1). ConA had a binding efficiency of $22 \%$ which is somewhat lower than the $30 \%$ reported previously [28] and may be due to the higher amount of proteins initially loaded onto the ConA resin herein. As expected, the most abundant plasma protein, albumin, was the major protein depleted with ConA affinity chromatography (seen as a large band at $c .65 \mathrm{kDa}$, Fig. 1C). Albumin is a non-glycosylated protein which accounts for 50$60 \%$ of the total plasma protein, therefore, the efficient depletion of it is crucial as it should 
facilitate the identification of lower abundance proteins which may otherwise have been masked [29].

Table 1: Total protein quantitation in ConA extraction experiment.

\begin{tabular}{lcc}
\hline Sample & Amount of protein $(\boldsymbol{\mu g})^{\mathbf{a}}$ & ${\text { Recovery } \%^{\mathbf{b}}}^{\text {Am }^{2}}$ \\
\hline Plasma & 3320 & 100 \\
Flow-through fraction & $2376 \pm 78$ & $71 \pm 2.3$ \\
Bound fraction & $713.6 \pm 62$ & $22 \pm 1.9$ \\
- Fraction A & $409.4 \pm 20$ & $12.3 \pm 0.6$ \\
- Fraction B & $148.8 \pm 9$ & $4.5 \pm 0.3$ \\
\hline
\end{tabular}

${ }^{\text {a }}$ Protein quantification was carried out in triplicate by BCA quantification kit (Fisher Scientific, Loughborough, UK).

${ }^{\mathrm{b}}$ All recoveries are expressed as the $\%$ of recovered proteins compared with $3320 \mu \mathrm{g}$ of protein in $50 \mu \mathrm{L}$ plasma.

Results are shown as mean $\pm \mathrm{SD}, \mathrm{n}=5$

To improve glycoprotein detection and further reduce the complexity of the sample, ConA bound proteins were fractionated using RP-SPE with stepwise elution using an increasing percentage of acetonitrile in water (in the presence of $0.1 \%$ TFA) (Fig. 1). SDS-PAGE profiling of the eight RP-SPE fractions collected from the whole plasma proteome and ConA captured proteins (Fig. 1, A and B respectively) revealed distinguishable protein profiles between whole and ConA fractionated plasma, and demonstrated clear differences in the protein constituents of the fractions. This provides evidence of successful sub-proteome and sub-glycoproteome fractionation. When comparing RP-SPE fraction profiles between whole and ConA fractionated plasma, we noticed that in ConA-treated plasma (Fig. 1B) some bands disappeared or were greatly diminished (e.g. albumin) while others were clearly more intense (e.g. transferrin bands at $75-80 \mathrm{kDa}$ and eluted at $35 \%$ and $40 \%$ organic solvent) than RP-SPE fractionated plasma proteome (Fig. 1A). This confirms specific enrichment of glycoproteins when ConA chromatography is employed as a first dimension with RP-SPE, compared with RP-SPE fractionation of the whole plasma. The reproducibility of the SDS-PAGE protein profiles of ConA-RP-SPE treated plasma between replicates is shown in Fig. S1 in Supplementary Data. 
The successfully developed two-step enrichment strategy (ConA affinity chromatography coupled with RP-SPE) provides a simple and reproducible protocol for efficient glycoprotein extraction from blood plasma. This protocol is potentially superior in not being limited by the capacity, sample number or the high-cost of immunodepletion columns commonly employed with proteomics workflows [30]. Similar to other depletion tools, the collected RP-SPE fractions are compatible with down-stream analysis by gel electrophoresis and MS methods $[22]$. 


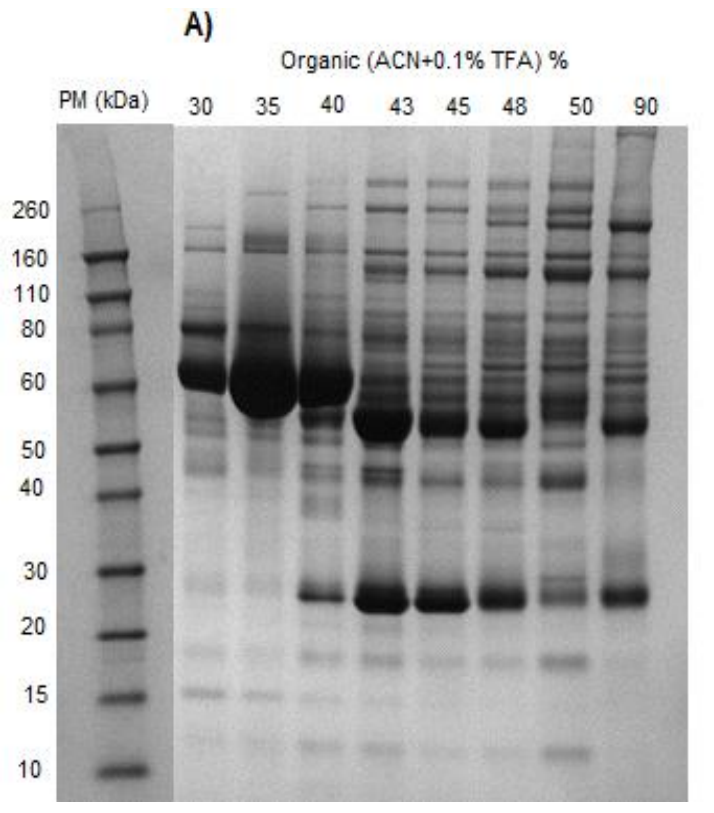

B)

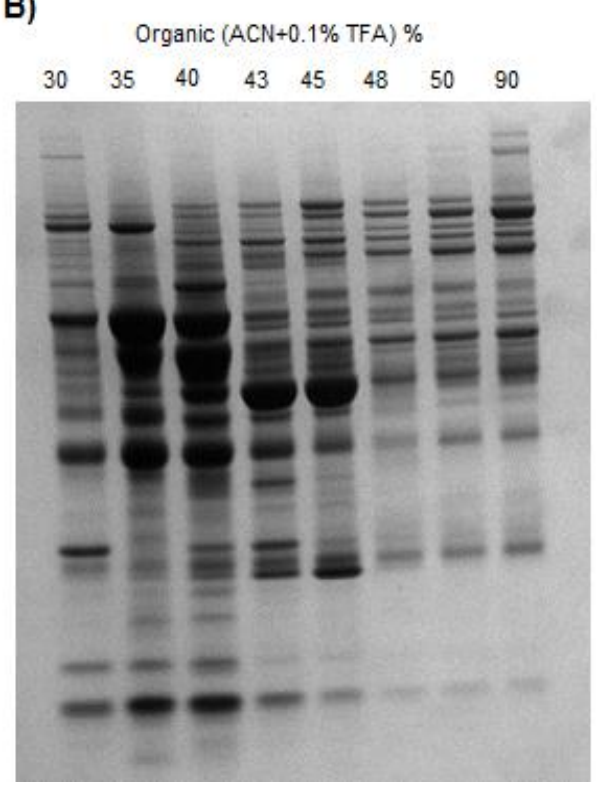

C)

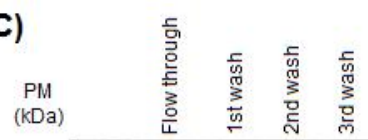

Fig. 1. Coomassie blue stained 1D SDS-PAGE. A) Crude human plasma ( $25 \mu \mathrm{L})$ protein profiles in eight RPSPE fractions eluted stepwise by increasing percentage of acetonitrile in $0.1 \%$ TFA in water $(v / v)$. The largest band in the gel represents albumin $(c .65 \mathrm{kDa})$ with the majority of it eluting at $35 \%(v / v)$ acetonitrile. B) Protein profiles of plasma $(50 \mu \mathrm{L})$ treated with ConA affinity chromatography followed by RP-SPE fractionation of the enriched glycoproteins. C) ConA non-retained proteins eluted in the flow-through and the three resin washes. The main ConA unbound protein was albumin $(c .65 \mathrm{kDa})$ with the majority of it eluted in the flow-through and gradually decreased following three sequential washes. 


\subsection{Identification of plasma proteins eluted from RP-SPE}

The combined results from both fractions identified 90 plasma proteins with a total of 758 matched peptides; 54 (379 matched peptides) and 62 (521 matched peptides) proteins were reproducibly identified in fractions A and B, respectively (Table S1 and S2 in Supplementary Data). Amongst the 90 proteins detected, 74 individual glycoproteins were identified with at least two unique peptides per protein, which is widely recognised as being sufficient for positive confirmation of protein identity [31,32]. The remaining 16 proteins were identified with one unique peptide but were reproducibly detected. Of the 16 proteins identified with lower confidence, only four were considered in the final profiling methodology (namely, serum amyloid P-component, complement component C9, pigment epithelium derived factor and $\mathrm{N}$-acetylmuramoyl-L-alanine amidase), and the identity of these signature peptides was further verified by a separate more sensitive analysis using EPI scan triggered by MRM (Fig. S2 in Supplementary Data).

Apart from albumin and some non-glycosylated proteins known to be associated with glycoproteins, all proteins captured by ConA were glycosylated, which increases confidence in the identification of individual glycoproteins. The identified glycoproteins are reported to be involved in a range of biological processes including inflammation, enzyme inhibition, coagulation/fibrinolysis pathways and metal and lipid metabolism (Table S1 and S2)

The combined results from both fractions confidently identified plasma proteins ranging in concentration from immunoglobulin IgG $(12 \mathrm{mg} / \mathrm{mL}$, [33]) to pigment epithelium-derived factor $(5 \mu \mathrm{g} / \mathrm{mL},[34])$, covering over three orders of magnitude. This dynamic range was likely achievable only by using 2D-LC; combining Con A enrichment with SPE fractionation, and enabled the identification of many proteins that could not be detected in either the whole plasma or ConA enriched fraction including peptides from less abundant glycoproteins such as corticosteroid binding globulin, fibronectin, lumican and pigment epithelium-derived 
factor. Such result highlighted the efficiency of the method developed as a powerful tool for extracting a glycoprotein subproteome. Extended dynamic range and improved coverage of low abundant glycoproteins (low $\mathrm{ng} / \mathrm{mL}$ ) has been reported previously when immunodepletion was coupled with glycoprotein extraction technique [10]. However, as previously discussed, the use of immunodepletion columns may lead to the loss of potential biomarkers and significantly increases costs and preparation times.

The list of identified glycoproteins herein (Table S1 and S2) was comparable with that reported in previous studies that used ConA and multi-lectin extraction methods [35-37]. We could confidently identify 78 glycoproteins with our method while previous studies using ConA glycoprotein extraction identified only 40 [38] and 49 [37] glycoproteins using $N$ glycopeptides. Our use of non-glycopeptide instead of glycopeptide-based identification enhanced both glycoprotein coverage and confidence in detection, and added to the improved throughput and analysis cost-effectiveness.

\subsection{Plasma glycoprotein profiling by targeted LC-MS/MS and method precision}

For targeted MS analysis; 54 clinically relevant glycoproteins, identified with high confidence, were selected to be monitored by LC-MS/MS; 38 from fraction A and 33 from fraction B (Table 2). Extracted ion chromatograms (XIC) for the targeted proteins, in human plasma fractions $\mathrm{A}$ and $\mathrm{B}$, are shown in Fig. 2 and 3 respectively. Chromatographic elution times for the individual signature peptide transitions were consistent throughout, showing CVs $<2 \%$ for all the monitored peptides through six experiments. The selection of suitable signature peptides and MRM transitions was conducted as described in section 2.6. Product ion analysis using an EPI experiment further confirmed the identities of all targeted peptides. 
Quantitative assessment of the profiling method revealed acceptable ( $\mathrm{CV} \leq 15 \%)$ analytical precision for the majority of the targeted glycoproteins, reflecting high reproducibility in the developed analytical workflow. The CV values ranged from $3.6 \%$ for complement C9 to $33 \%$ for fibrinogen $\alpha$ chain (median CVs $11.8 \%$ ). $83.5 \%$ (46 out of 55 proteins) of the MRM had a precision $\leq 15 \%$ of which $38 \%$ were $\leq 10 \%$ as shown in Fig. 4 . These values for achieved analytical precision make most of the assays suitable for quantitative protein measurement in clinical samples in line with the FDA guidelines for bioanalytical method [27].

The analytical precision we have reported represents the net variability of the whole workflow. However, we evaluated variation in the instrument performance as it can affect the reproducibility of an analytical assay in label-free workflows. Analysis of replicate LCMS/MS injections ( $n=6)$ revealed an acceptable level of precision for the MRM transitions (median CV $7.1 \%$ ) with the majority $(70 \%)$ of the MRM assays produced $\mathrm{CV}$ values of $\leq$ $10 \%$. This highlights the reproducible performance of the instrument, sample clean-up and digestion workflow which together yielded acceptable analytical precision for the majority of the glycoproteins in this study.

A previous study that used a label-free strategy reported a slight improvement in analytical precision and lower $\mathrm{CV}$ values (range 1.2-11.2\%, median 6.3\%) compared to the present work [26]. However, the study measured only 18 glycoproteins [26], all of which are included in our list of 54, and all showed acceptable reproducibility (CV\% $\leq 15 \%)$. Additionally, the developed methodology herein had improved precision and lower CV values (median CV $11.8 \%$ ) compared to previous studies that applied label-free targeted LC-MS/MS to quantify a different set of plasma proteins and had median CVs of 18.9\% [39] and 16.5\% [18].

Of note, most of the published targeted glycoprotein profiling methods applied SIS strategies and resulted in expectedly higher quantitation reproducibility (majority of the assays had CVs $<10 \%)[20,21,40,41]$ compared to our methodology. However, the reported number of 
glycoproteins they profiled was limited to less than 15 and probably reflects the high costs of synthetic labelled peptide standards that have to be prepared for each signature peptide monitored in the SIS workflow. Our more cost-effective label-free approach enabled us to profile a greater number of glycoproteins with most measurements having $\mathrm{CV}$ values approaching those of SIS studies [41], and may be useful in applications such as clinical biomarker discovery. By careful optimisation of sample clean-up and exploiting the excellent stability of the modern micro-flow rate LC-MS/MS systems, compared with nano-LC systems [39], we were able to minimise the interference from the biological matrix and improve the precision of protein quantitation. Moreover, the use of conventional micro-flow LC system improved the throughput of our method by reducing the LC-MS/MS analysis time to 20 min, compared with the 120 min typically required with nano-LC [26]. 
Table 2: MRM transitions and CV values for the targeted glycoproteins.

\begin{tabular}{|c|c|c|c|c|c|c|c|}
\hline No. & Protein & Fraction & $\begin{array}{l}\text { Signature peptide } \\
\text { sequence }\end{array}$ & MS1/MS2 & $\begin{array}{l}\text { Fragment } \\
\text { ion }\end{array}$ & CV (\%) & Reference \\
\hline 1 & a-1- Acid glycoprotein & A & $\begin{array}{l}\text { NWGLSVYADKPET } \\
\text { TK }\end{array}$ & $570.3 / 273.1$ & a2 & 12.8 & {$[24,25]$} \\
\hline 2 & a-1-Antichymotrypsin & B & ADLSGITGAR & $\begin{array}{l}480.8 / 574.3 \\
480.8 / 661.4\end{array}$ & $\begin{array}{l}\text { y6 } \\
\text { y7 }\end{array}$ & 13.4 & [24], Mascot \\
\hline 3 & a-1-Antitrypsin & $\begin{array}{l}A \\
B\end{array}$ & LSITGTYDLK & $556.0 / 797.4$ & y7 & $\begin{array}{l}11.7 \\
10.0\end{array}$ & {$[25 ; 26]$} \\
\hline 4 & $\alpha-2-$ Antiplasmin & $\mathrm{B}$ & LGNQEPGGQTALK & $656.8 / 771.4$ & y8 & 16.0 & [23] \\
\hline 5 & $\alpha-1$-Betaglycoprotein & $A$ & LETPDFQLFK & $619.3 / 243.1$ & b2 & 11.5 & [23] \\
\hline 6 & $\alpha-2-H S$ glycoprotein & $\begin{array}{l}A \\
B\end{array}$ & FSVVYAK & $\begin{array}{l}\mathbf{4 0 7 . 6 / 4 8 0 . 3} \\
407.6 / 579.5\end{array}$ & $\begin{array}{l}\text { y4 } \\
\text { y5 }\end{array}$ & $\begin{array}{l}7.2 \\
14.8\end{array}$ & Mascot \\
\hline 7 & a-2-Macroglobulin & $\begin{array}{l}A \\
B\end{array}$ & $\begin{array}{l}\text { LLIYAVLPTGDVIGD } \\
\text { SAK }\end{array}$ & $615.7 / 530.3$ & $\mathrm{y} 11^{+2}$ & $\begin{array}{l}22.5 \\
12.6\end{array}$ & [23] \\
\hline 8 & $\beta$-2-glycoprotein 1 & $A$ & ATVVYQGER & $511.8 / 652.3$ & y5 & 11.9 & [23] \\
\hline 9 & Afamin & $\begin{array}{l}A \\
B\end{array}$ & DADPDTFFAK & $563.8 / 825.4$ & y7 & $\begin{array}{l}10.0 \\
13.0\end{array}$ & [23] \\
\hline 10 & Albumin & $A$ & LVNEVTEFAK & $575.3 / 937.5$ & y8 & 14.4 & [23] \\
\hline 11 & Angiotensinogen & B & ALQDQLVLVAAK & $634.9 / 501.4$ & y5 & 11.8 & [23] \\
\hline 12 & Antithrombin-III & $\begin{array}{l}A \\
B\end{array}$ & DDLYVSDAFHK & 437.2/704.3 & y6 & $\begin{array}{l}11.0 \\
9.7\end{array}$ & {$[23 ; 24]$} \\
\hline 13 & Apolipoprotein A-1 & $\mathrm{B}$ & ATEHLSTLSEK & $405.9 / 363.2$ & y3 & 9.5 & [23] \\
\hline 14 & Apolipoprotein A-II & B & SPELQAEAK & $486.8 / 443.2$ & $y 8^{+2}$ & 12.8 & [23] \\
\hline 15 & Apolipoprotein D & $\begin{array}{l}\text { A } \\
B\end{array}$ & NILTSNNIDVK & $\begin{array}{l}615.8 / 1003.5 \\
615.8 / 890.5\end{array}$ & $\begin{array}{l}\text { y9 } \\
\text { y8 }\end{array}$ & $\begin{array}{l}13.1 \\
11.2\end{array}$ & [25] \\
\hline 16 & $\begin{array}{l}\text { C4b-Binding protein } \\
a \text {-chain }\end{array}$ & $A$ & $\begin{array}{l}\text { WTPYQGCEALCCP } \\
\text { EPK }\end{array}$ & $998.7 / 855.2$ & $y 14^{+2}$ & 20.8 & Mascot \\
\hline 17 & CD5 antigen-like & B & IWLDNVR & $\begin{array}{l}458.4 / 616.4 \\
458.4 / 503.3\end{array}$ & $\begin{array}{l}\text { y5 } \\
\text { y4 }\end{array}$ & 12.5 & Mascot \\
\hline 18 & Ceruloplasmin & $\begin{array}{l}A \\
B\end{array}$ & EYTDASFTNR & $\begin{array}{l}602.3 / 695.3 \\
602.3 / 911.4\end{array}$ & $\begin{array}{l}\text { y6 } \\
\text { y8 }\end{array}$ & $\begin{array}{l}14.6 \\
7.1\end{array}$ & {$[23 ; 24]$} \\
\hline 19 & Clusterin & $\begin{array}{l}A \\
B\end{array}$ & ASSIIDELFQDR & $\begin{array}{l}697.5 / 565.3 \\
697.5 / 922.4\end{array}$ & $\begin{array}{l}\text { y4 } \\
\text { y7 }\end{array}$ & $\begin{array}{l}14.7 \\
8.1\end{array}$ & [26] \\
\hline 20 & Complement C3 & $\begin{array}{l}A \\
B\end{array}$ & TGLQEVEVK & $501.8 / 603.3$ & y5 & $\begin{array}{l}22.5 \\
4.0\end{array}$ & [23] \\
\hline 21 & $\begin{array}{l}\text { Complement C4- } \beta- \\
\text { chain }\end{array}$ & $\begin{array}{l}\text { A } \\
B\end{array}$ & VGDTLNLNLR & $\begin{array}{l}557.8 / 629.4 \\
557.8 / 843.5\end{array}$ & $\begin{array}{l}\text { y5 } \\
\text { y7 }\end{array}$ & $\begin{array}{l}13.4 \\
11.0\end{array}$ & [23] \\
\hline 22 & Complement C5 & B & TDAPDLPEENQAR & $\begin{array}{l}728.3 / 584.8 \\
728.3 / 843.4\end{array}$ & $\begin{array}{l}y 10^{+2} \\
y 7\end{array}$ & 14.6 & Mascot \\
\hline 23 & Complement C6 & $A$ & SEYGAALAWEK & $\begin{array}{c}\mathbf{6 1 2 . 8 / 1 0 0 8 . 6} \\
612.8 / 845.6 \\
612.8 / 717.5\end{array}$ & $\begin{array}{l}\text { y9 } \\
\text { y8 } \\
\text { y6 }\end{array}$ & 15.4 & Mascot \\
\hline 24 & $\begin{array}{l}\text { Complement C8 } \\
\alpha \text {-chain }\end{array}$ & $A$ & MESLGITSR & $497.5 / 533.4$ & y5 & 17.3 & Mascot \\
\hline 25 & Complement C9 & $\begin{array}{l}\text { A } \\
B\end{array}$ & AIEDYINEFSVR & $\begin{array}{l}\text { 728.5/1271.6 } \\
728.5 / 1027.5\end{array}$ & $\begin{array}{l}\text { y10 } \\
\text { y8 }\end{array}$ & $\begin{array}{l}8.5 \\
3.6\end{array}$ & [24] \\
\hline 26 & Complement factor B & $A$ & EELLPAQDIK & $578.3 / 372.2$ & b3 & 11.6 & [23] \\
\hline 27 & Complement factor $\mathrm{H}$ & $A$ & SPDVINGSPISQK & $671.4 / 830.4$ & y8 & 7.6 & [23] \\
\hline 28 & Complement factor I & $A$ & GLETSLAECTFTK & $\begin{array}{l}729.1 / 856.5 \\
729.1 / 785.6\end{array}$ & $\begin{array}{l}y 7 \\
y 6\end{array}$ & 12.8 & Mascot \\
\hline 29 & $\begin{array}{l}\text { Corticosteroid binding } \\
\text { globulin }\end{array}$ & B & EENFYVDETTVVK & $\begin{array}{c}787.2 / 890.5 \\
787.2 / 791.4 \\
787.2 / 1053.5\end{array}$ & $\begin{array}{l}\text { y8 } \\
\text { y7 } \\
\text { y9 }\end{array}$ & 12.6 & Mascot \\
\hline 30 & Fibrinogen $\alpha$-chain & $A$ & GSESGIFTNTK & $\begin{array}{l}570.8 / 780.4 \\
570.8 / 610.3\end{array}$ & $\begin{array}{l}\text { y7 } \\
\text { y5 }\end{array}$ & 32.7 & {$[23 ; 24]$} \\
\hline 31 & Fibrinogen $\beta$-chain & $A$ & QGFGNVATNTDGK & $\begin{array}{l}654.8 / 706.3 \\
654.8 / 635.3\end{array}$ & $\begin{array}{l}\text { y7 } \\
\text { y6 }\end{array}$ & 30.7 & {$[23 ; 24]$} \\
\hline
\end{tabular}


Table 2: Continued

\begin{tabular}{|c|c|c|c|c|c|c|c|}
\hline No. & Protein & Fraction & $\begin{array}{l}\text { Signature peptide } \\
\text { sequence }\end{array}$ & MS1/MS2 & $\begin{array}{l}\text { Fragment } \\
\text { ion }\end{array}$ & CV (\%) & Reference \\
\hline 32 & Fibrinogen $y$-chain & $A$ & DTVQIHDITGK & $\begin{array}{l}409.6 / 217.1 \\
409.5 / 533.3\end{array}$ & $\begin{array}{l}\text { b2 } \\
\text { y5 }\end{array}$ & 30.8 & {$[23 ; 24]$} \\
\hline 33 & Fibronectin & B & IYLYTLNDNAR & $\begin{array}{r}678.5 / 803.4 \\
678.5 / 966.4 \\
678.5 / 1079.5\end{array}$ & $\begin{array}{l}\text { y7 } \\
\text { y8 } \\
\text { y9 }\end{array}$ & 25.9 & Mascot \\
\hline 34 & Hepatoglobin $\beta$ chain & $\begin{array}{l}A \\
B\end{array}$ & DIAPTLTLYVGK & $646.1 / 496.5$ & $y 9^{+2}$ & $\begin{array}{l}15.2 \\
6.7\end{array}$ & Mascot \\
\hline $\begin{array}{l}35 \\
36\end{array}$ & $\begin{array}{l}\text { Hemopexin } \\
\text { Histidin rich } \\
\text { glycoprotein }\end{array}$ & $\begin{array}{l}A \\
A\end{array}$ & $\begin{array}{l}\text { NFPSPVDAAFR } \\
\text { GGEGTGYFVDFSVR }\end{array}$ & $\begin{array}{l}610.8 / 959.6 \\
746.2 / 869.6 \\
746.2 / 623.4\end{array}$ & $\begin{array}{l}\text { y9 } \\
\text { y7 } \\
\text { y5 }\end{array}$ & $\begin{array}{l}12.9 \\
7.8\end{array}$ & $\begin{array}{l}{[24]} \\
\text { Mascot }\end{array}$ \\
\hline 37 & Heparin cofactor II & B & TLEAQLTPR & $\begin{array}{l}514.8 / 814.4 \\
514.8 / 685.4\end{array}$ & $\begin{array}{l}\text { y7 } \\
\text { y6 }\end{array}$ & 7.1 & [23] \\
\hline 38 & $\begin{array}{l}\text { Inter-a-trypsin } \\
\text { inhibitor heavy chain } \\
(\mathrm{H} 1)\end{array}$ & $\begin{array}{l}\text { A } \\
B\end{array}$ & AAISGENAGLVR & $579.4 / 902.5$ & y9 & $\begin{array}{l}10.2 \\
23.7\end{array}$ & [24] \\
\hline 39 & $\begin{array}{l}\text { Insulin-like growth } \\
\text { factor-binding protein } \\
\text { acid labile subunit }\end{array}$ & B & LAELPADALGPLQR & $\begin{array}{l}732.6 / 1037.7 \\
732.6 / 570.4 \\
732.6 / 894.6\end{array}$ & $\begin{array}{l}\text { y10 } \\
\text { y5 } \\
\text { b9 }\end{array}$ & 11.0 & Mascot \\
\hline 40 & Kallikrein & A & LSMDGSPTR & $\begin{array}{l}482.6 / 632.4 \\
482.6 / 850.5 \\
482.6 / 763.5\end{array}$ & $\begin{array}{l}\text { y6 } \\
\text { y8 } \\
\text { y7 }\end{array}$ & 12.6 & Mascot \\
\hline 41 & Kallistatin & B & IAPANADFAFR & $\begin{array}{l}596.8 / 540.3 \\
596.8 / 504.9 \\
596.8 / 840.4\end{array}$ & $\begin{array}{l}\mathrm{y} 4 \\
\mathrm{y} 9^{+2} \\
\mathrm{y} 7\end{array}$ & 6.9 & Mascot \\
\hline 42 & Kininogen & A & TVGSDTFYSFK & $626.3 / 1051.5$ & y9 & 11.8 & [23] \\
\hline 43 & Lumican & $A$ & SLEDLQLTHNK & $\begin{array}{l}649.5 / 853.5 \\
649.5 / 549.5 \\
649.5 / 612.4\end{array}$ & $\begin{array}{l}\text { Y7 } \\
\text { Y9+2 } \\
\text { Y5 }\end{array}$ & 26.6 & Mascot \\
\hline 44 & $\begin{array}{l}\mathrm{N} \text {-acetylmuramoyl-L- } \\
\text { alanine amidase }\end{array}$ & B & GCPDVQASLPDAK & $\begin{array}{l}679.5 / 571.0 \\
679.5 / 430.3\end{array}$ & $\begin{array}{l}y 11^{+2} \\
y 4\end{array}$ & 14.7 & Mascot \\
\hline 45 & $\begin{array}{l}\text { Pigment epithelium } \\
\text { derived factor }\end{array}$ & B & LAAAVSNFGYDLYR & $\begin{array}{c}780.4 / 1134.6 \\
780.4 / 933.6 \\
780.4 / 1047.5\end{array}$ & $\begin{array}{l}\text { y9 } \\
\text { y7 } \\
\text { y8 }\end{array}$ & 10.0 & Mascot \\
\hline 46 & $\begin{array}{l}\text { Plasma protease C1 } \\
\text { inhibitor }\end{array}$ & $\begin{array}{l}A \\
B\end{array}$ & LLDSLPSDTR & $558.8 / 575.3$ & y5 & $\begin{array}{l}19.2 \\
6.9\end{array}$ & [25] \\
\hline 47 & Protein AMBP & $\begin{array}{l}A \\
B\end{array}$ & TVAACNLPIVR & $607.4 / 484.3$ & y4 & $\begin{array}{l}9.9 \\
10.2\end{array}$ & Mascot \\
\hline 48 & Plasminogen & $A$ & LFLEPTR & $\begin{array}{l}438.3 / 615.3 \\
438.3 / 502.3\end{array}$ & $\begin{array}{l}\text { y5 } \\
\text { y4 }\end{array}$ & 13.2 & {$[23 ; 24]$} \\
\hline 49 & Prothrombin & $A$ & ETAASLLQAGYK & $626.3 / 879.5$ & y8 & 13.2 & {$[23 ; 24]$} \\
\hline 50 & $\begin{array}{l}\text { Serum-amyloid P- } \\
\text { component }\end{array}$ & $A$ & VGEYSLYIGR & $\begin{array}{l}578.8 / 708.4 \\
578.8 / 508.3\end{array}$ & $\begin{array}{l}\text { y6 } \\
\text { y4 }\end{array}$ & 11.7 & [23] \\
\hline 51 & $\begin{array}{l}\text { Serum } \\
\text { paraoxonase/aryleste } \\
\text {-rase1 }\end{array}$ & B & IQNILTEEPK & $\begin{array}{l}592.8 / 943.5 \\
592.8 / 716.6\end{array}$ & $\begin{array}{l}\text { y8 } \\
\text { y6 }\end{array}$ & 7.9 & Mascot \\
\hline 52 & $\begin{array}{l}\text { Thyroxine-binding } \\
\text { globulin }\end{array}$ & B & GWVDLFVPK & $530.8 / 244.1$ & b2 & 15.1 & Mascot \\
\hline 53 & Transferrin & $\begin{array}{l}\text { A } \\
B\end{array}$ & SVIPSDGPSVACVK & $708.7 / 558.9$ & $\mathrm{y} 11^{+2}$ & $\begin{array}{l}12.6 \\
5.6\end{array}$ & Mascot \\
\hline 54 & Vitronectin & $\begin{array}{l}A \\
B\end{array}$ & DVWGIEGPIDAAFTR & $\begin{array}{c}823.9 / 947.5 \\
823.9 / 1076.6\end{array}$ & $\begin{array}{l}\text { y9 } \\
\text { y10 }\end{array}$ & $\begin{array}{l}12.9 \\
13.2\end{array}$ & [24] \\
\hline 55 & Zinc-a-2-glycoprotein & $A$ & EIPAWVPFDPAAQITK & $892.0 / 770.9$ & $y 14^{+2}$ & 7.5 & [23] \\
\hline
\end{tabular}

* Validated transitions are presented in bold.

** Swiss-Prot codes (accession No.) for the proteins are presented in table S1 and S2.

*** MS1/MS2 represents precursor and product ions. 


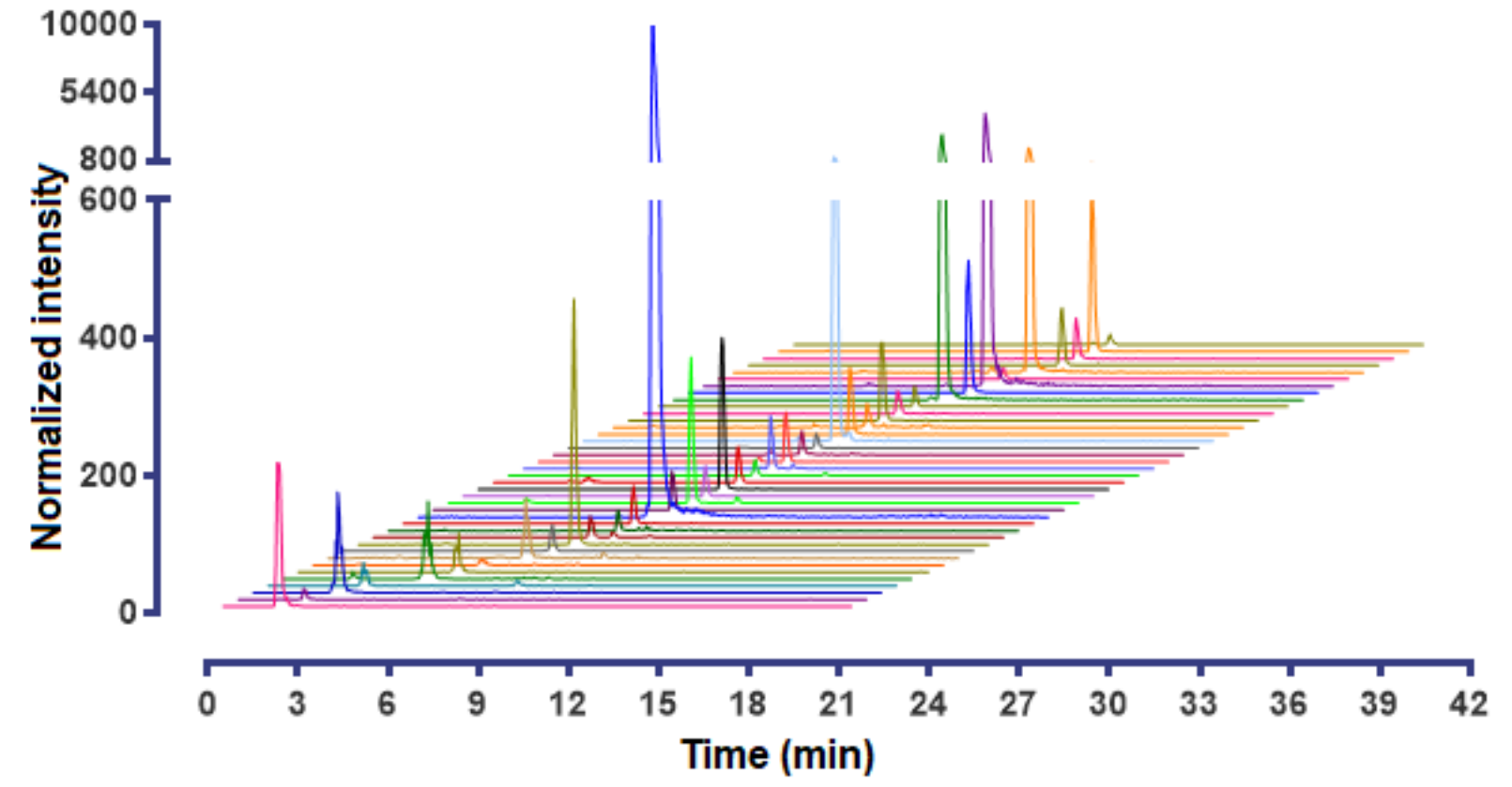

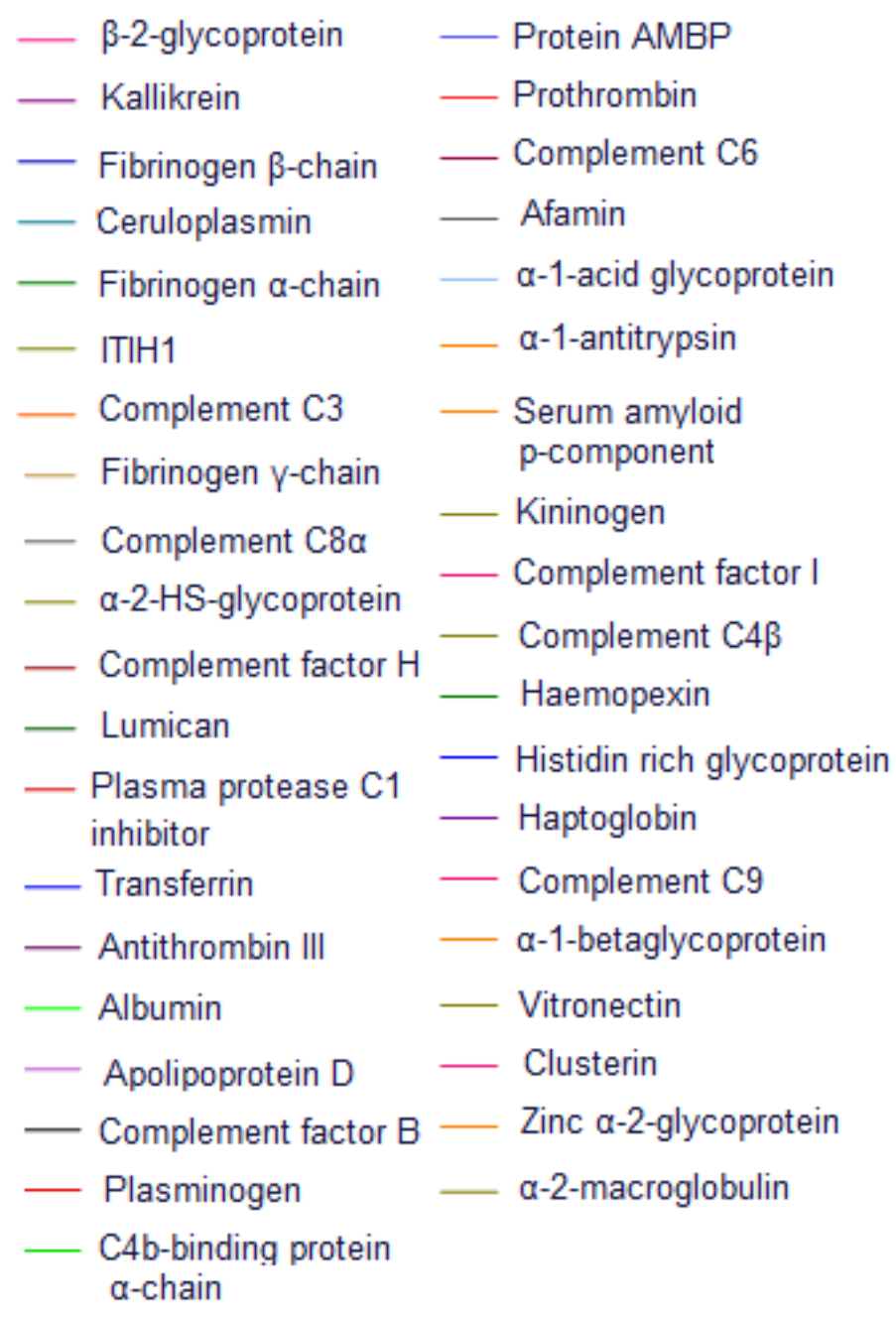

Fig. 2. Extracted ion chromatograms of human plasma extract for 39 glycoproteins profiled in fraction A using targeted LC-MS/MS. The signal intensities varied with the highest being for transferrin $\left(\sim 1 \times 10^{6}\right)$ and the lowest for lumican $\left(\sim 7 \times 10^{3}\right)$. The analysis time was 21 min and signal intensity for each protein was normalised to transferrin. ITIH1 refers to inter-alpha-trypsin inhibitor heavy chain H1. Protein names in the right side are listed in the same order as presented in the figure (starting from the protein with the shortest retention time). 


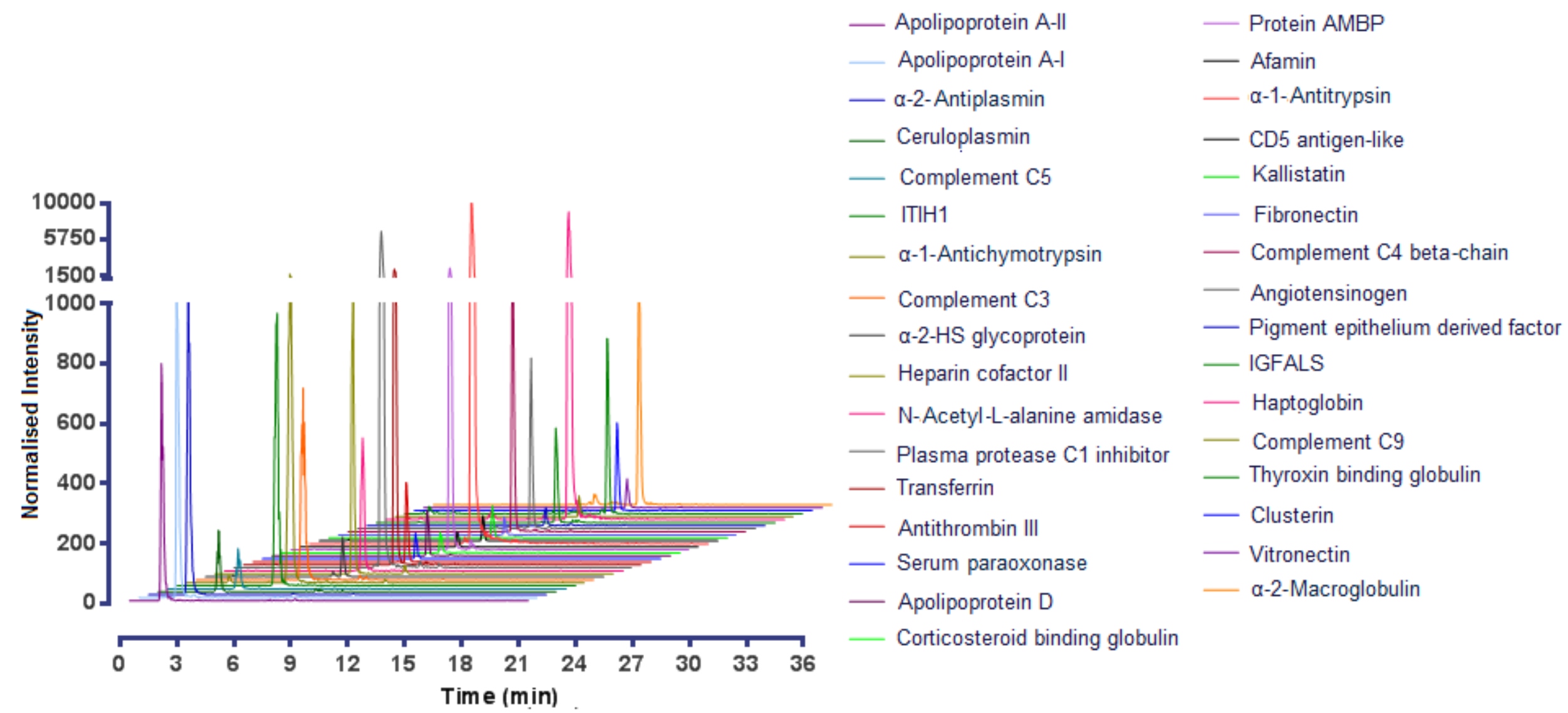

Fig. 3. Extracted ion chromatograms of human plasma extract for 33 glycoproteins profiled in fraction B using targeted LC-MS/MS. The signal intensities varied with the highest being for $\alpha-1$-antitrypsin $\left(\sim 8 \times 10^{5}\right)$, and the lowest for corticosteroid binding globulin $\left(\sim 4.5 \times 10^{3}\right)$. The analysis time was 21 min and signal intensity for each protein was normalised to $\alpha$-1-antitrypsin. ITIH1 refers to inter-alpha-trypsin inhibitor heavy chain H1. Protein names in the right side are listed in the same order as presented in the figure (starting from the protein with the shortest retention time). 


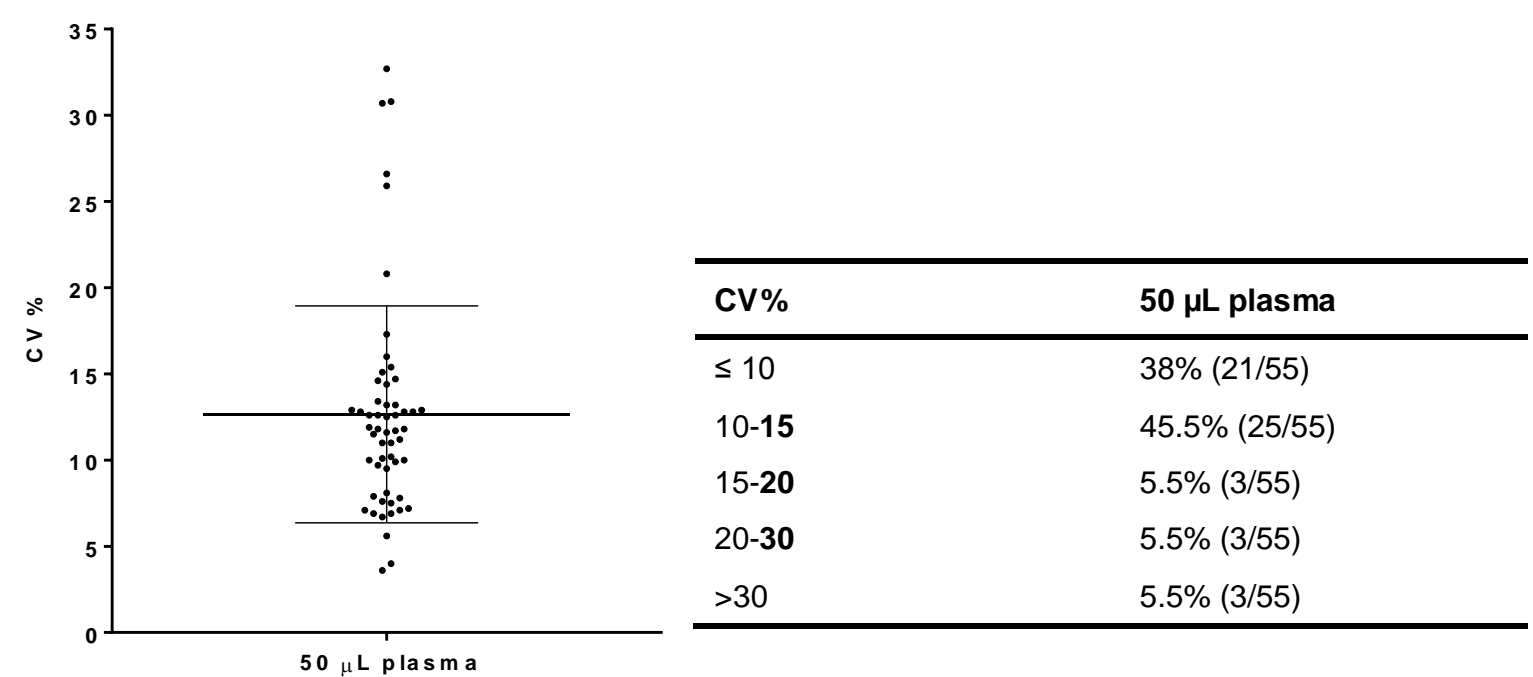

Fig. 4. Distribution of coeffecient of variation (CV) for the 55 proteins (54 clinically relevant glycoproteins and albumin) targeted in $50 \mu \mathrm{L}$ plasma extract using the developed method. For proteins monitored in both fractons (A and $\mathrm{B}$ ), the best $\mathrm{CV}$ value was presented. $\mathrm{CV}$ values for each protein in each fraction is presented in Table 2. Error bars presented in the graph refers to the mean \pm $\mathrm{SD}, \mathrm{n}=6$

3.4. Application of the method to measuring small changes in glycoprotein composition in plasma and serum samples

\section{Ammonium sulphate treated plasma}

Ammonium sulphate precipitation was used as a model system to investigate the suitability of this workflow to detect minor changes in glycoprotein composition that may be apparent in biological/clinical samples, for example when comparing treated versus control cohorts.

As a result of ammonium sulphate precipitation, the levels of some glycoproteins in human plasma were altered compared with control plasma and these small, but measurable changes, were readily detected by our LC-MS/MS method (Fig. 5A and 5B). Comparison with plasma controls revealed that the levels of eight high-to-moderate abundance proteins (namely; fibrinogen $\alpha$ and $\beta, \beta 2$ glycoprotein 1, plasminogen, haptoglobin, fibronectin, apolipoprotein 
A-1 and transferrin) were significantly lower in ammonium sulphate treated plasma (Fig. 5B), which supports the use of ammonium sulphate fractionation as a simple and cost-effective approach for changing plasma protein abundance [42]. These results are in agreement with a previous study which reported a comparable list of altered proteins using $20 \%$ ammonium sulphate plasma fractional precipitation [43].

A)

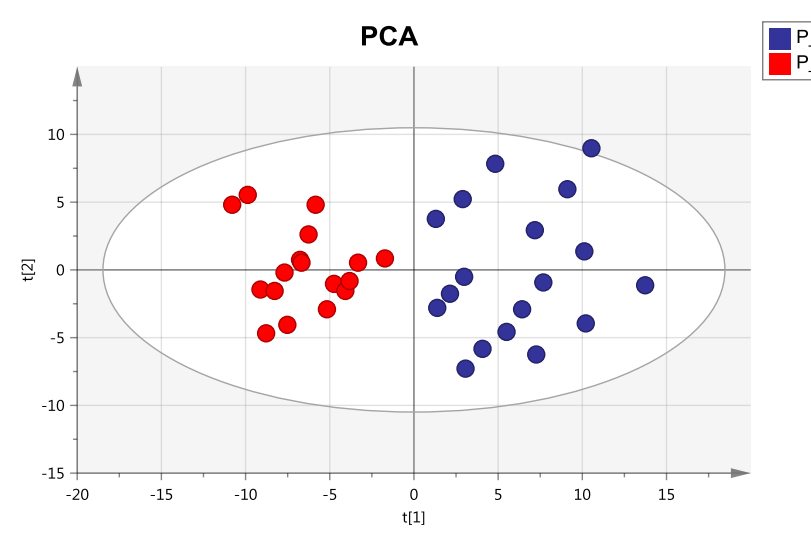

B)

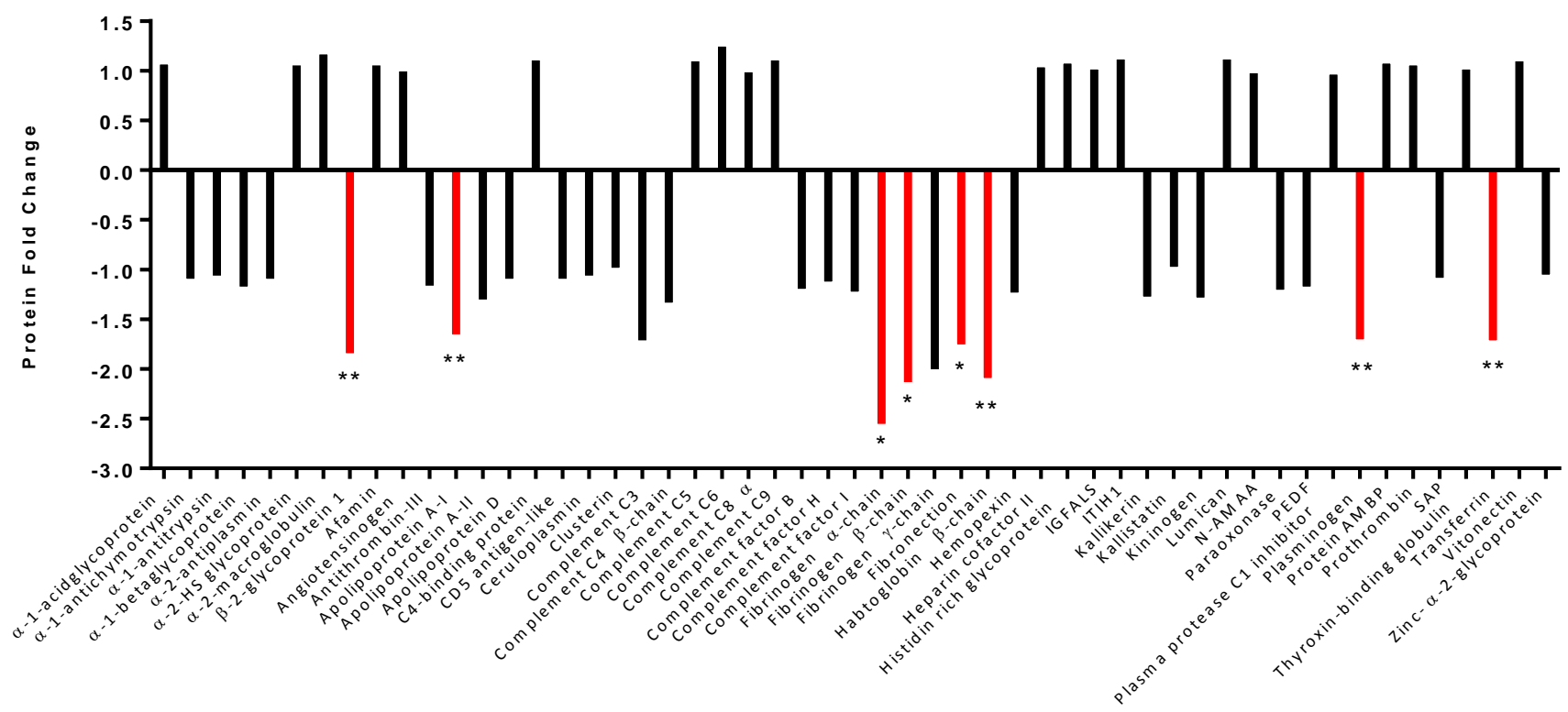

Fig. 5. A) Principle component analysis (PCA) score plot of targeted LC-MS/S data sets for control normal plasma (blue colour) and ammonium sulphate treated plasma samples (red colour). B) Protein fold changes between ammonium sulphate treated plasma and plasma control samples. Protein levels significantly altered are presented in red (two-tailed independent $t$-test, $\mathrm{p}$ value $\leq 0.05$ is statistically significant, $* p<0.05$, ** $p<0.01)$

ITHI1: inter-alpha-trypsin inhibitor heavy chain H1, IGFALS: insulin like growth factor binding protein acid labile subunit, N-AMAA is N-acetylmuramoyl-L-alanine amidase, PEDF: pigment epithelium derived factor, SAP: serum amyloid P-component. 


\section{Plasma and serum samples}

The ability of the method to distinguish between plasma and serum samples was investigated as an alternative test to determine the suitability of the method to detect changes in plasma glycoprotein profiles. Consistent with previous reports that compared the glycoproteome between plasma and serum samples [13], the coagulation factors fibrinogen ( $\alpha, \beta$ and $\gamma)$ were absent from our tested serum samples as a result of the clotting process (Fig. $3 \mathrm{~S}$ in Supplementary). The other remaining targeted glycoproteins were detected in both serum and plasma with no statistically significant differences in their levels between the two biological fluids.

Taken together, the above applications confirmed that the precision and the specificity of the developed profiling method is sufficient to detect small differences in the abundance of targeted glycoproteins in different samples as observed with ammonium sulphate treated plasma, and plasma and serum samples.

\section{Conclusion}

A new label-free targeted methodology using two-step fractionation coupled with conventional microflow LC-MS/MS was developed and validated to profile 54 selected clinically relevant human plasma glycoproteins. The developed method has high throughput potential in terms of sample preparation since it avoids costly and time consuming stages such as immunodepletion enrichment, and complex deglycosylation, as used with many existing glycoprotein studies $[10,35,44]$. Also, the sample preparation protocol avoids the depletion of moderately abundant glycoproteins (e.g. protease inhibitors and coagulation factors) that might be relevant disease biomarkers [34, 45]. Although the method, in its current format, has limited ability to measure and identify proteins of low abundance (low 
$\mathrm{ng} / \mathrm{mL}$ concentration), some of which may have a diagnostic potential, many of the proteins in our list have significant relationships to crucial disease and very few of them have been simultaneously investigated in the same sample set, making our assay a useful starting point for investigating these proteins in different disease states.

The use of conventional micro-flow as opposed to a nano-LC system resulted in more stable electrospray performance, increased chromatographic precision and reduced analysis times, while maintaining sufficient sensitivity. These properties contributed to the acceptable precision we observed and made the method more applicable for routine use when high throughput analysis is required.

The acceptable analytical precision $(\mathrm{CV} \% \leq 15)$ achieved for most of the assays showed that label-free methodology can be a cost-effective alternative to SIS workflows when applied to relative protein quantification, especially when targeting a large number of proteins in bioanalytical measurements. Additionally, the method reproducibility is superior to that achieved with immunoblotting (CVs in the range from 20-40\%) typically used for the validation of potential disease biomarkers. Alternatively, label-free targeted LC-MS/MS offers a complementary, preliminary approach for the verification of a large number of putative candidate biomarkers prior to establishing more costly isotope labelling targeted LCMS/MS or ELISA assays for promising biomarkers.

\section{Acknowledgment}

This work was funded by the University of Jordan as part of Lina A. Dahabiyeh's PhD programme at the University of Nottingham.

\section{Declarations of Interest}

The authors declare that they have no conflict of interest. 


\section{References}

1. C.H.Wong, Protein glycosylation: New challenges and opportunities, J Org Chem. 70 (2005) 4219-4225.

2. W. Morelle, K. Canis, F. Chirat, V. Faid, J.C. Michalski, The use of mass spectrometry for the proteomic analysis of glycosylation. Proteomics, 6 (2006) 3993-4015.

3. J. S. Ross, J. A. Fletcher, G.P. Linette, J. Stec, E. Clark, M. Ayers, W.F. Symmans, L. Pusztai, K.J. Bloom, The HER-2/neu gene and protein in breast cancer 2003: Biomarker and target of therapy. Oncologist. 8 (2003) 307-325.

4. J. R. Prensner, M. A. Rubin, J. T. Wei, A. M. Chinnaiyan, Beyond PSA: The next generation of prostate cancer biomarkers. Sci Transl Med. 4 (2012) doi: 10.1126/scitranslmed.3003180.

5. M. Bhattacharjee, R. Sharma, R.Goel, L. Balakrishnan, S. Renuse, J. Advani, S.T. Gupta, R. Verma, S.M Pinto, N.R.Sekhar, B. Nair, T.S.K. Prasad, H.C. Harsha, R. Jois, S. Shankar, A. Pandery, A multilectin affinity approach for comparative glycoprotein profiling of rheumatoid arthritis and spondyloarthropathy. Clin proteomics. 10 (2013) doi: 10.1186/15590275-10-11.

6. N.Yang, S. Feng, K. Shedden, X. Xie, Y. Liu,C.J. Rosser, D.M. Lubman, S. Goodison, Urinary glycoprotein biomarker discovery for bladder cancer detection using LC/MS-MS and label-free quantification. Clin Cancer Res. 17 (2011) 3349-3359.

7. R. Schiess, B. Wollscheid, and R. Aebersold, Targeted proteomic strategy for clinical biomarker discovery. Mol Oncol. 3 (2009) 33-44.

8. H. Liu, N. Zhang, D. Wan, M. Cui, Z. Liu, S. Liu, Mass spectrometry-based analysis of glycoproteins and its clinical applications in cancer biomarker discovery. Clin Proteomics. 11 (2014) doi: 10.1186/1559-0275-11-14.

9. H. Zhang, X.J. Li, D.B. Martin, R. Aebersold, Identification and quantification of N-linked glycoproteins using hydrazide chemistry, stable isotope labeling and mass spectrometry. Nat Biotechnol. 21 (2003) 660-666.

10. T. Liu, W. J. Qian, M. A. Gritsenko, D. G. Camp, M.E. Monroe, R.J. Moore, R.D. Smith, Human plasma N-glycoproteome analysis by immunoaffinity subtraction, hydrazide chemistry, and mass spectrometry. J Proteome Res. 4 (2005). 2070-2080.

11. S. Pan, Y. Wang, J.F. Quinn, E.R. Peskind, D. Waichunas, J.T. Wimberger, J. Jin, J.G. Li, D. Zhu, C. Pan, J. Zhang, Identification of glycoproteins in human cerebrospinal fluid with a complementary proteomic approach. J Proteome Res. 5 (2006). 2769-2779. 
12. Z. Roth, G. Yehezkel, and I. Khalaila, Identification and quantification of protein glycosylation. Int J Carbohydr Chem, 2012. doi.org/10.1155/2012/640923

13. Z. Yang, W. S. Hancock, T. R. Chew, L. Bonilla, A study of glycoproteins in human serum and plasma reference standards (HUPO) using multilectin affinity chromatography coupled with RPLC-MS/MS. Proteomics. 5 (2005) 3353-3366.

14. T. Patwa, C. Li, D. M. Simeone, D. M. Lubman. Glycoprotein analysis using protein microarrays and mass spectrometry. Mass Spectrom Rev. 29 (2010) 830-844.

15. Y. Qui, T. H. Patwa, L. Xu, K. Shedden, D. E. Misek, M. Tuck, G. Jin, M. T. Ruffin, D. K. Turgeon, S. Synal, R. Bresalier, N. Marcon, D. E. Brenner, D. M. Lubman, Plasma glycoprotein profiling for colorectal cancer biomarker identification by lectin glycoarray and lectin blot. J Proteome Res. 7 (2008) 1693-1703.

16. Y. H. Ahn, J.Y. Kim, and J.S. Yoo, Quantitative mass spectrometric analysis of glycoproteins combined with enrichment methods. Mass Spectrom Rev. 34 (2015) 148-165.

17. R. Zhu, E. Song, A. Hussein, F. H. Kobeissy, Y. Mechref, Glycoproteins enrichment and LCMS/MS glycoproteomics in central nervous system applications, Methods Mol Biol. 1598 (2017) 213-227.

18. H. Zhang, Q. Liu, L. J. Zimmerman, A. J. Ham, R. J. Slebos, J. Rahman, T. Kikuchi, P. P. Massion, D. P. Carbone, D. Billheimer, D. C. Liebler, Methods for peptide and protein quantitation by liquid chromatography-multiple reaction monitoring mass spectrometry. Mol Cell Proteomics. 10 (2011) doi: 10.1074/mcp.M110.006593.

19. D. C. Liebler , L. J. Zimmerman, Targeted quantitation of proteins by mass spectrometry, Biochemistry. 52 (2013) 3797-3806.

20. Y. H. Ahn, P. M. Shin, E. S. Ji, H. Kim, J. S. Yoo, A lectin-coupled, multiple reaction monitoring based quantitative analysis of human plasma glycoproteins by mass spectrometry. Anal Bioanal Chem. 402 (2012) 2101-2112.

21. Y. H. Ahn, P. M. Shin, N. R. Oh, G. W. Park, H. Kim, J. S. Yoo, A lectin-coupled, targeted proteomic mass spectrometry (MRM MS) platform for identification of multiple liver cancer biomarkers in human plasma, J Proteomics. 75 (2012) 5507-5515.

22. D. J. Tooth, V. Gopala Krishna, R. Layfield, An economical high-throughput protocol for multidimensional fractionation of proteins, Int J Proteomics. 2012 (2012) doi:10.1155/2012/735132 
23. M. A. Kuzyk, D. Smith, J. Yang, Y. J. Cross, A. M. Jackson, D. B. Hardie, N. L. Anderson, C. H. Borchers, Multiple reaction monitoring-based, multiplexed, absolute quantitation of 45 proteins in human plasma, Mol Cell Proteomics. 8 (2009) 1860-1877.

24. L. Anderson, C. L. Hunter, Quantitative mass spectrometric multiple reaction monitoring assays for major plasma proteins, Mol Cell Proteomics. 5 (2006) 573-588.

25. D. Domanski, A. J. Percy, J. Yang, A. Chambers, J. S. Hill, G. V. Freue, C. H. Borchers, MRM-based multiplexed quantitation of 67 putative cardiovascular disease biomarkers in human plasma, Proteomics. 12 (2012) 1222-1243.

26. M. J. McKay, J. Sherman, M. T. Laver, M. S. Baker, S. J. Clarke, M. P. Molloy, The development of multiple reaction monitoring assays for liver-derived plasma proteins, Proteomics Clin Appl. 1 (2007) 1570-1581.

27. U.S Department of Health and Human Services Food and Drug Administration, Center for Drug Evaluation and Research (CDER), Bioanalytical Method Validation, Guidance for Industry, May 2018, Available at:

https://www.fda.gov/downloads/drugs/guidances/ucm070107.Pdf

28. M. Madera, B. Mann, Y. Mechref, M. V. Novotny, Efficacy of glycoprotein enrichment by microscale lectin affinity chromatography, J Sep Sci. 31 (2008) 2722-2732.

29. N. L. Anderson, N. G. Anderson, The human plasma proteome - History, character, and diagnostic prospects, Mol Cell Proteomics. 1 (2002) 845-867.

30. L. Dayona, M. Kussmanna, Proteomics of human plasma: A critical comparison of analytical workflows in terms of effort, throughput and outcome, EuPA open proteomics. 1 (2013) 8-16.

31. R. Chen, Y. Tan , M. Wang, F. Wang, Z. Yao, L. Dong, M. Ye, H. Wang, H. Zou, Development of glycoprotein capture-based label-free method for the high-throughput screening of differential glycoproteins in hepatocellular carcinoma, Mol Cell Proteomics. 10 (2011) doi: 10.1074/mcp.M110.006445

32. Y. Wang, X. Ao, H. Vuong, M. Konanur, F. R. Miller, S. Goodison, D. M. Lubman , Membrane glycoproteins associated with breast tumor cell progression identified by a lectin affinity approach, J Proteome Res. 7 (2008) 4313-4325.

33. S. L. Wu, G. Choudhary, M. Ramström, J. Bergquist, W. S. Hancock, Evaluation of shotgun sequencing for proteomic analysis of human plasma using HPLC coupled with either ion trap or Fourier transform mass spectrometry, J Proteome Res. 2 (2003) 383-393. 
34. G. L. Hortin, D. Sviridov, N. L. Anderson, High-abundance polypeptides of the human plasma proteome comprising the top 4 logs of polypeptide abundance, Clin Chem. 54 (2008) 1608-1616.

35. Z. Yang, W. S. Hancock, Approach to the comprehensive analysis of glycoproteins isolated from human serum using a multi-lectin affinity column, J Chromatogr A. 1053 (2004) 79-88.

36. K. S. Shamsi, A. Pierce, A. S. Ashton, D. G. Halade, A. Richardson, S. E. Espinoza, Proteomic Screening of Glycoproteins in Human Plasma for Frailty Biomarkers, J Gerontol A Biol Sci Med Sci. 67 (2012) 853-864.

37. K. Sparbier, A. Asperger, A. Resemann, I. Kessler, S. Koch, T. Wenzel, G. Stein, L. Vorwerg , D. Suckau, M. Kostrzewa, Analysis of glycoproteins in human serum by means of glycospecific magnetic bead separation and LC-MALDI-TOF/TOF analysis with automated glycopeptide detection, J Biomol Tech. 18 (2007) 252-258.

38. T. Ishihara, I. Fukuda, A. Morita, Y. Takinami, H. Okamoto, S. Nishimura, Y. Numata, Development of quantitative plasma N-glycoproteomics using label-free 2-D LC-MALDI MS and its applicability for biomarker discovery in hepatocellular carcinoma. J Proteomics. 74 (2011) 2159-2168.

39. R. T. Blankley, C. Fisher, M. Westwood, R. North, P. N. Baker, M. J. Walker , A. Williamson, A. D. Whetton, W. Lin, L. McCowan, C. T. Roberts, G. J. Cooper, R. D. Unwin, J. E. Myers, A Label-free Selected Reaction Monitoring Workflow Identifies a Subset of Pregnancy Specific Glycoproteins as Potential Predictive Markers of Early-onset Pre-eclampsia, Mol Cell Proteomics. 12 (2013) 3148-3159.

40. Y. H. Ahn, Y. S. Kim, E. S. Ji, J. Y. Lee, J. A. Jung, J. H. Ko, J. S. Yoo, Comparative Quantitation of Aberrant Glycoforms by Lectin-Based Glycoprotein Enrichment Coupled with Multiple-Reaction Monitoring Mass Spectrometry, Anal Chem. 82 (2010) 4441-4447.

41. Y. H. Ahn, E. S. Ji, P. M. Shin, K. H. Kim, Y. S. Kim, J. H. Ko, J. S. Yoo, A multiplex lectinchannel monitoring method for human serum glycoproteins by quantitative mass spectrometry, Analyst. 137 (2012) 691-703.

42. O. Odunuga, and A. Shazhko, Ammonium sulfate precipitation combined with liquid chromatography is sufficient for purification of bovine serum albumin that is suitable for most routine laboratory applications, Biochem Compd. (2013) doi: 10.7243/2052-9341-1-3

43. S.Saha, S. Halder, D. Bhattacharya, D. Banerjee, A. Chakrabarti, Fractional precipitation of plasma proteome by ammonium sulphate: case studies in leukemia and thalassemia, Proteomics \& Bioinformatics. 5 (2012) 163-171. 
44. J. Martosella , N. Zolotarjova, H. Liu, G. Nicol, B. E. Boyes, Reversed-phase highperformance liquid chromatographic prefractionation of immunodepleted human serum proteins to enhance mass spectrometry identification of lower-abundant proteins, J Proteome Res. 4 (2005) 1522-1537.

45. A. V. Rapkiewicz, V. Espina, E. F. Petricoin 3rd, L. A. Liotta , Biomarkers of ovarian tumours, Eur J Cancer. 40 (2004) 2604-2612. 


\section{Supplementary Tables and Figures}
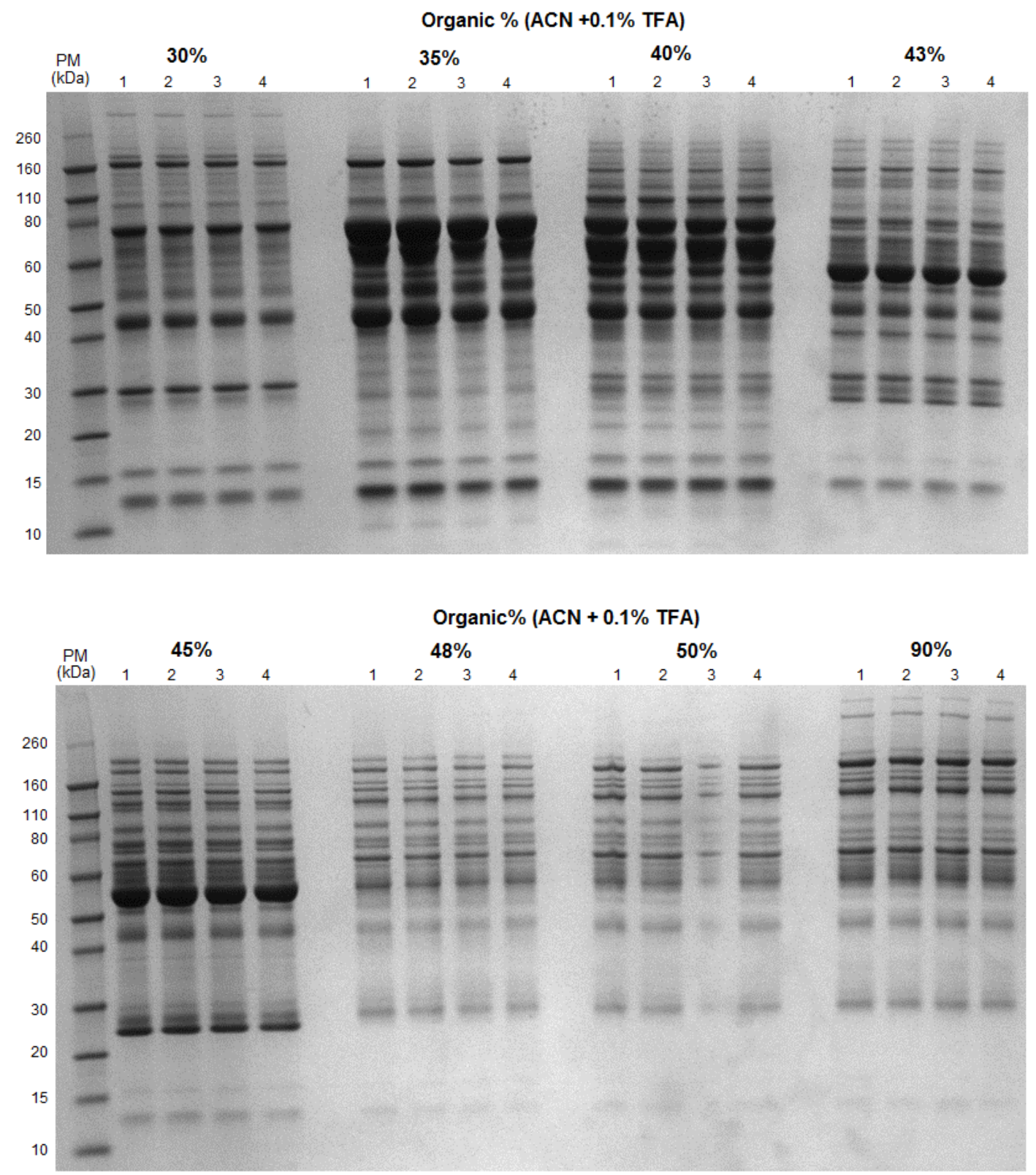

Figure S1: Coomassie blue stained 1D SDS-PAGE for protein profiles across four human plasma replicates treated with ConA affinity chromatography followed by RP-SPE fractionation of retained glycoproteins. Consistent protein profiles were observed between the four biological replicates in the eight fractions eluted by increasing percentage of acetonitrile in $0.1 \%$ TFA using RP-SPE. 

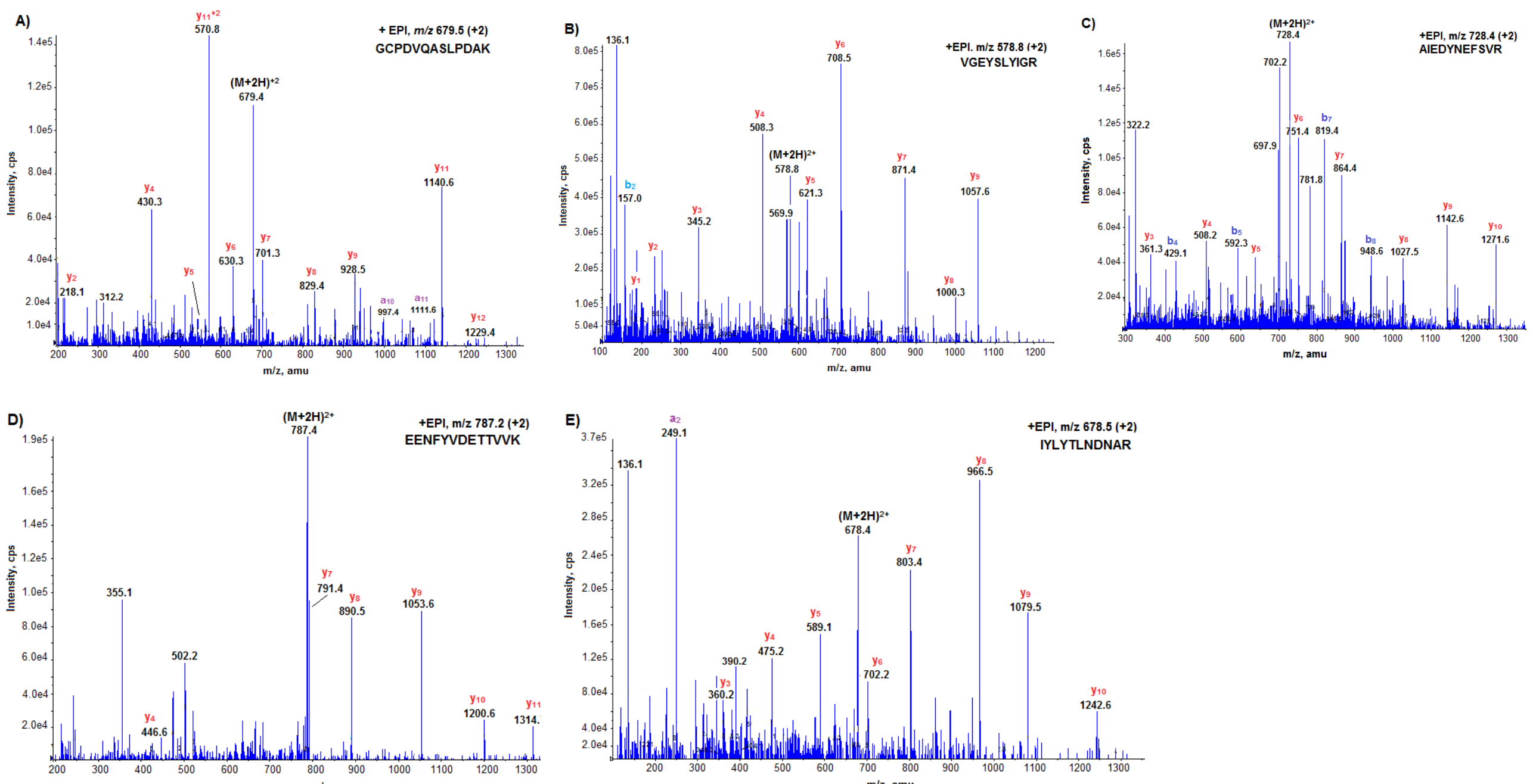

Figure S2: MS/MS spectra of selected signature peptides of relatively low abundance glycoproteins in human plasma extracts. Spectra were obtained by EPI scan triggered by MRM. A) N-acetylmuramoyl-L-alanine amidase B) Serum amyloid P-component C) Complement component 9 D) Corticosteroidbinding globulin E) Fibronectin. A, B and C proteins were consistently identified with only one peptide using Mascot. 


\section{Plasma}

XIC of MRM: $570.8 / 610.3$

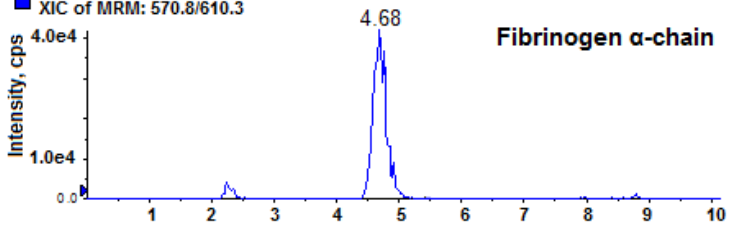

- XIC of MRM: $654.8 / 706.3$

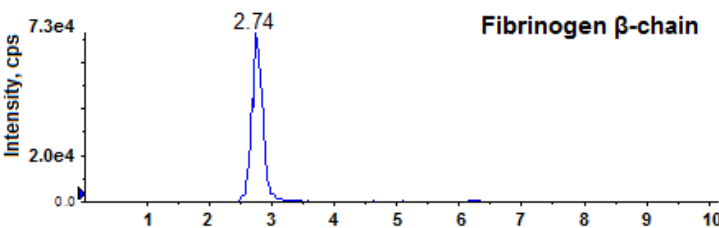

- XIC of MRM: 409.6/217.1

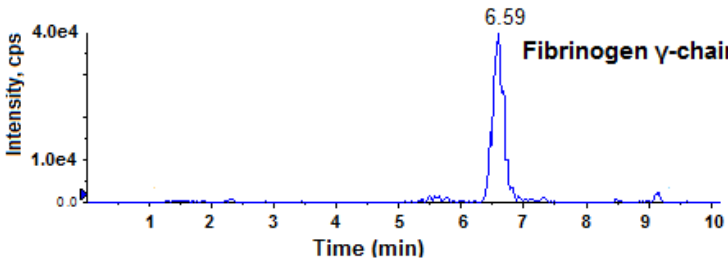

\section{$\underline{\text { Serum }}$}

- XIC of MRM: $570.8 / 610.3$

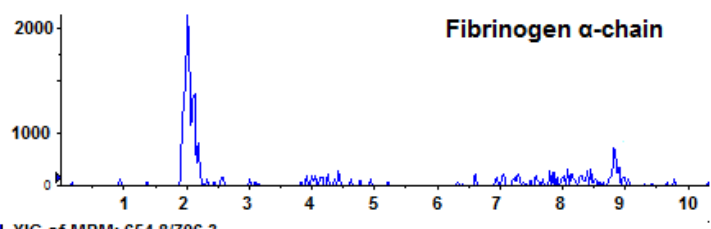

- XIC of MRM: 654.8/706.3 Fibrinogen $\beta$-chain

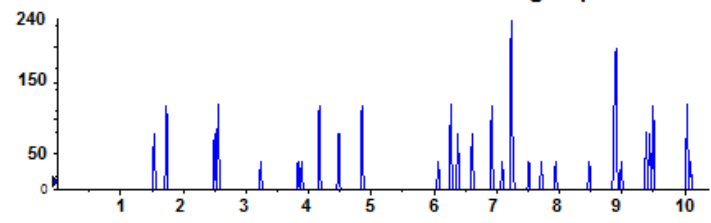

- XIC of MRM: 409.6/217.1

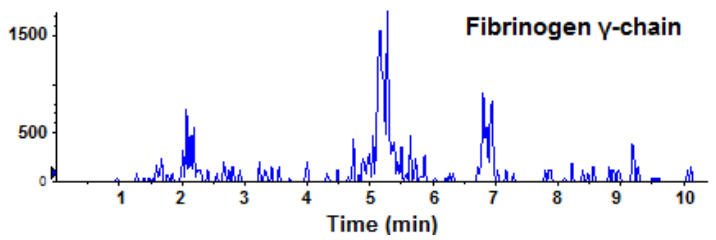

Figure S3: XIC of MRM for fibrinogen $\alpha, \beta$ and $\gamma$ extracted from the plasma and serum tryptic digests analysed by the developed glycoprotein profiling method. Note the clearance of these proteins due to clotting processes during sample preparation. 